\title{
PENGARUH BERKUMUR AIR REBUSAN DAUN KEMANGI TERHADAP PH SALIVA PADA SISWA/I SDN 060933 SIMPANG POS PADANG BULAN MEDAN TAHUN 2017
}

\author{
Ngena Ria \\ Dosen Jurusan Keperawatan Gigi Poltekkes Kemenkes Medan
}

\begin{abstract}
Abstrak
Kemangi mengandung senyawa flavonoid, eugenol, arginin, etanol, boron, dan minyak atsiri. Kandungan minyak atsiri pada kemangi mampu memberikan rasa khas yang dapat merangsang sekresi saliva saat berkumur air rebusan daun kemangi. Kecepatan sekresi saliva dipengaruhi oleh sifat rangsangan. Sedangkan naik turunnya $\mathrm{pH}$ saliva bergantung pada kecepatan sekresi, dimana penurunan $\mathrm{pH}$ saliva merupakan faktor pendukung terjadinya karies gigi. Tujuan penelitian ini dilakukan untuk mengetahui pengaruh Berkumur Air Rebusan Daun Kemangi Terhadap pH Saliva Pada Siswa/I kelas V SDN 060933 Simpang Pos Padang Bulan Medan Tahun 2017. Jenis penelitian ini adalah penelitian analitik. Metode yang digunakan quaisi experiment, dengan pendekatan cross sectional. Rancangan dalam penelitian ini adalah time design series. Adapun cara pengambilan sampel dengan Purposive Sampling, menggunakan siswa/i kelas V SDN 060933 Simpang Pos Padang Bulan Medan sebanyak 33 siswa, dengan menggunakan Test Paper Dental Saliva $\mathrm{pH}$ Indikator untuk mengetahui kriteria $\mathrm{pH}$ saliva. Penelitian ini mengunakan uji Wilcoxon Signed Ranks Test dan uji Paired T-test. Hasil penelitian diketahui terjadi perubahan criteria $\mathrm{pH}$ saliva yaitu asam dari 39,39\% menjadi 9,09 , basa dari $39,39 \%$ menjadi $54,54 \%$ dan netral darri $21,21 \%$ menjadi $36,36 \%$. Menunjukkan bahwa ada pengaruh berkumur air rebusan daun kemangi terhadap $\mathrm{pH}$ saliva. Hasl uji statistik dengan menggunakan Wilcoxon Signed Ranks Test dihasilkan nilai signifikasi 0,004 (p-value <0,05). Disarankan kepada siswa untuk berkumur menggunakan rebusan daun kemangi sebagai alternatif tindakan pencegahan terjadinya karies.
\end{abstract}

Kata kunci : Air rebusan daun kemangi, pH saliva

\section{Latar Belakang}

Tujuan pembangunan kesehatan mengacu pada Undang-undang No.36 tahun 2009 pasal 3 tentang kesehatan yang menjelaskan bahwa pembangunan kesehatan bertujuan untuk meningkatkan kesadaran, kemauan dan kemampuan hidup sehat bagi setiap orang agar terwujud derajat kesehatan masyarakat yang setinggi-tingginya, sebagai investasi bagi pembangunan sumber daya manusia yang produktif secara sosial dan ekonomi.

Pembangunan bidang kesehatan merupakan bagian integral dari pembangunan nasional, termasuk bidang kesehatan gigi yang tidak boleh ditinggalkan karena kesehatan gigi dan mulut mempengaruhi kesehatan secara keseluruhan. Untuk mewujudkan derajat kesehatan yang optimal bagi masyarakat diselenggarakan upaya kesehatan dengan pendekatan pemeliharaan, peningkatan kesehatan (promotif), pencegahan penyakit (preventif), penyembuhan penyakit (kuratif) dan pemulihan kesehatan (rehabilitatif) yang dilaksanakan secara menyeluruh terpadu dan berkesinambungan.

Berdasarkan Riset Kesehatan Dasar (RISKESDAS) tahun 2007 diketahui bahwa prevalensi karies aktif pada penduduk Indonesia mencapai $72,1 \%$.
Di pulau Jawa persentase penduduk karies aktif tertinggi pada Daerah Istimewa Yogyakarta (DIY) yaitu $52,3 \%$. Karies gigi merupakan penyakit yang paling banyak dijumpai di rongga mulut bersama-sama dengan penyakit periodontal, sehingga merupakan masalah utama kesehatan gigi dan mulut. Proses karies dan penyakit periodontal disebabkan karena adanya interaksi antara tiga faktor yaitu host (gigi, gingiva, saliva), penjamu (bakteri/plak) dan makanan kariogenik (sukrose).

Dalam keadaan normal, gigi geligi selalu dibasahi oleh saliva. Ludah atau saliva adalah cairan kental yang diproduksi oleh kelenjar ludah. Ludah terdiri dari $99,5 \%$ air, sisanya adalah zat-zat seperti Kalsium, Fosfor, Natrium, Magnesium dan lain-lain.

Kerentanan gigi terhadap karies banyak bergantung kepada lingkungannya. Bila seseorang mengkonsumsi makanan dan minuman yang mengandung karbohidrat maka beberapa bakteri penyebab karies dirongga mulut akan memulai memproduksi asam, sehingga terjadi demineralisasi yang berlangsung selama 20-30 menit setelah makan. Diantara periode makan, saliva akan bekerja menetralisir asam dan membantu proses remineralisasi. Peran saliva sangat penting sekali. Kandungan ion 
Kalsium dan Fosfat pada saliva mampu meremineralisasikan karies yang masih dini. Kemampuan saliva dalam melakukan remineralisasi dipengaruhi oleh pHnya. Semakin asam suatu $\mathrm{pH}$ saliva maka semakin mudah terjadinya karies. Sistem buffer asam karbonat-bikarbonat, serta kandungan amonia dan urea dalam saliva dapat menyangga dan menetralkan penurunan $\mathrm{pH}$ yang terjadi saat bakteri plak sedang memetabolisme gula. Kapasitas penyangga dan $\mathrm{pH}$ saliva erat hubungannya dengan kecepatan sekresinya.

Penurunan kecepatan sekresi saliva dapat diikuti oleh peningkatan jumlah Streptococcus Mutans dan kuman-kuman Laktobasilus. Dengan demikian, aktivitas karies yang tinggi dapat terjadi apabila kecepatan sekresi ludah berkurang. Kecepatan sekresi jenis kelenjar sangat tergantung pada sifat rangsangan (stimulasi). Kelenjar ludah dapat dirangsang dengan berbagai cara, misalnya secara mekanis dengan mengunyah makanan keras atau permen karet dan kimiawi, oleh rangsangan rasa seperti asam, manis, asin, pahit dan pedas.

Rangsangan kimiawi juga dapat dilakukan dengan berkumur air rebusan daun kemangi. Kandungan minyak atsiri yang ada pada kemangi mampu memberikan rasa khas yang dapat merangsang serta mempercepat keluarnya saliva dan diduga dapat berpengaruh terhadap $\mathrm{pH}$ saliva. Kemangi merupakan salah satu tanaman yang baik untuk kesehatan gigi. Kemangi mengandung senyawa Flavonoid dan Eugenol, Arginin, Anetol, Boron, dan minyak Atsiri. Minyak Atsiri dan ekstrak Etanol dalam daun kemangi mampu menghambat pertumbuhan bakteri yang ada di dalam mulut terutama bakteri Streptococcus Mutans yang merupakan salah satu bakteri penyebab karies. Sifat antibakteri yang ada pada kemangi dapat dimanfaatkan sebagai obat kumur tradisional guna mencegah pertumbuhan bakteri dan dalam mulut.

Salah satu upaya pencegahan penyakit gigi dan mulut adalah dengan menjaga kebersihan gigi dan mulut agar bakteri tidak tumbuh dan mencegah tertimbun plak lebih lama. Upaya kesehatan gigi pada anak-anak harus dilakukan sedini mungkin, karena gigi anak-anak usia sekolah dasar mudah terkena karies. Pada umumnya keadaan kebersihan mulut anak lebih jelek dibandingkan dengan orang dewasa karena pola makan anak yang sering makan makanan dan minuman yang bersifat kariogenik. Anak usia sekolah dasar memiliki periode gigi bercampur yaitu terdapatnya gigi sulung dan gigi permanen. Pada masa ini dioerlukan pencegahan sedini mungkin. Dari latar belakang, maka peneliti ingin mengetahui pengaruh berkumur air rebusan daun kemangi terhadap $\mathrm{pH}$ saliva pada siswa/i SDN 060933 Simpang Pos Padang Bulan Medan.

\section{Perumusan Masalah}

Perumusan masalah penelitian adalah : "Bagaimanakah pengaruh berkumur air rebusan daun kemangi terhadap $\mathrm{pH}$ saliva pada siswa/i kelas V SDN 060933 Simpang Pos Padang Bulan Medan ?"

\section{Tujuan Penelitian}

Mengetahui pengaruh berkumur air rebusan daun kemangi terhadap $\mathrm{pH}$ saliva pada siswa/i kelas V SDN 060933 Simpang Pos Padang Bulan Medan.

\section{Tujuan Khusus}

1. Mengetahui $\mathrm{pH}$ saliva pada siswa/i sebelum berkumur air rebusan daun kemangi.

2. Mengetahui $\mathrm{pH}$ saliva pada siswa/i sesudah berkumur air rebusan daun kemangi.

3. Mengetahui perbedaan sebelum dan sesudah berkumur air rebusan daun kemangi terhadap $\mathrm{pH}$ saliva.

\section{Kerangka Konsep}

V. Independen V. Dependen

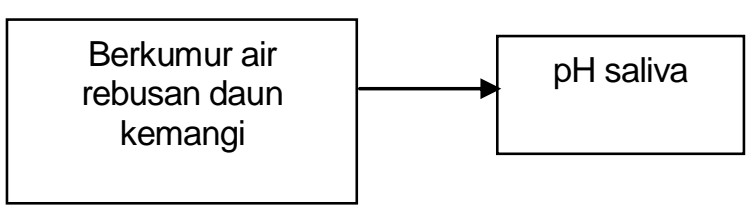

\section{Definisi Operasional}

\section{Berkumur air rebusan daun kemangi}

Berkumur air rebusan daun kemangi adalah tindakan berkumur dengan menggunakan air rebusan daun kemangi.

\section{pH saliva}

Derajat $\mathrm{pH}$ adalah derajat keasaman saliva.

$\mathrm{pH}$ saliva netral adalah derajat keasaman saliva pada $\mathrm{pH} 7$.

$\mathrm{pH}$ saliva asam adalah derajat keasaman saliva pada $\mathrm{pH}$ $<7$.

$\mathrm{pH}$ basa adalah derajat keasaman saliva pada $\mathrm{pH}>7$.

\section{Hipotesis}

Ho : Tidak ada pengaruh berkumur air rebusan daun kemangi terhadap $\mathrm{pH}$ saliva pada siswa/i SDN kelas V 060933 Simpang Pos Padang Bulan Medan tahun 2017.

Ha : Ada pengaruh berkumur air rebusan daun kemangi terhadap $\mathrm{pH}$ saliva pada siswa/i SDN kelas V SDN 060933 Simpang Pos Padang Bulan Medan tahun 2017.

\section{Jenis dan Desain Penelitian}

Jenis penelitian yang digunakan adalah penelitian analitik. Metode yang digunakan dalam penelitian adalah quaisi eksperimen atau sering disebut dengan eksperimen semu yaitu suati penelitian dengan adanya suatu perlakuan terhadap kelompok sampel tetapi tidak ada kelompok kontrol (semua sampel mendapat perlakuan). (Notoatmodjo, 2005)

Peneliti melakukan penelitian dengan menggunakan pendekatan Cross Sectional yang merupakan penelitian sesaat, dimana pengambilan data variabel pengaruh dan variabel terpengaruh dilakukan pada waktu yang bersamaan. Rancangan dalam penelitian ini menggunakan 
rancangan pre-test and post-test (Arikunto, 2006). Didalam desain ini observasi dilakukan sebanyak 2 kali, yaitu sebelum eksperimen dan sesudah eksperimen. $\mathrm{pH}$ saliva diukur sebelum dan sesudah berkumur dengan air rebusan daun kemangi.

Rancangan penelitian ini secara sistematis dapat ditulis sebagai berikut :

\begin{tabular}{|l|l|l|}
\hline Pre-test & Perlakuan & Post-test \\
\hline 01 & $\mathrm{X}$ & 02 \\
\hline
\end{tabular}

Keterangan :

$01=$ Pengambilan dan pengukuran $\mathrm{pH}$ saliva sebelum berkumur air rebusan daun kemangi.

$\mathrm{X}=$ Perlakuan berkumur air rebusan daun kemangi.

$02=$ Pengambilan dan pengukuran $\mathrm{pH}$ saliva setelah berkumur air rebusan daun kemangi.

Dalam penelitian ini yang diukur adalah $\mathrm{pH}$ saliva sebelum dan sesudah berkumur dengan air rebusan daun kemangi.

\section{Populasi}

Populasi adalah keseluruhan subjek penelitian. Populasi dalam penelitian ini adalah siswa/i kelas 060933 Simpang Pos Padang Bulan Medan yang berjumlah 368 orang.

\section{Sampel}

Sampel adalah sebagian atau wakil populasi yang diteliti. Pengambilan sampel secara purposive sampling sampel diambil berdasarkan tujuan tertentu. Sampel penelitian adalah siswa kelas V yang berjumlah 33 orang.

\section{Jenis dan Cara Pengumpulan Data}

Jenis data yang digunakan ada dua yaitu data primer dan data sekunder. Data primer yaitu data tentang pengaruh saliva yang telah diambil dengan teknik pemeriksaan langsung ke mulut siswa/I yang menjadi sampel. Sedangkan data sekunder adalah data yang dibutuhkan sebagai pelengkap didalam penelitian yang didapat dari pihak sekolah yaitu data tentang jumlah siswa/i kelas V SDN 060933 Simpang Pos Padang Bulan Medan.

\section{D.1. Prosedur Penelitian}

Persiapan

Alat terdiri dari :

1. Kertas lakmus

2. Cangkir plastik

3. Alat tulis

4. Ember

5. Hasil pengukuran

6. Stopwatch

Bahan terdiri dari :

1. Air rebusan daun kemangi

2. Tissu

\section{Pelaksanaan Kegiatan}

1. Peneliti melakukan perkenalan dengan seluruh sampel.

2. Sampel diinstruksikan meludah ke dalam cawan plastik A, kemudian diukur $\mathrm{pH}$ saliva dengan menggunakan kertas indikator.

3. Setelah itu setiap sampel diberi air rebusan daun kemangi sebanyak $20 \mathrm{ml}$ yang sudah disiapkan untuk berkumur. Sampel diinstruksikan untuk berkumur air rebusan daun kemangi selama 30 detik dengan gerakan yaitu pipi kiri dan kanan secara teratur dan kepala menunduk. Kemudian dibuang ke dalam ember yang telah disediakan.

4. Setelah berkumur sampel diinstruksikan meludah kedalam cawan plastik B, kemudian diukur $\mathrm{pH}$ saliva dengan menggunakan kertas indikator.

5. Membandingkan $\mathrm{pH}$ saliva sebelum dan sesudah berkumur air rebusan daun kemangi.

\section{Pengolahan dan Analisis Data \\ Pengolahan Data}

Teknik pengolahan data yang digunakan yaitu dengan computer yang disajikan dalam tabel distribusi frekuensi.

\section{Analisa Data}

Analisa data dilakukan setelah pengolahan data dari hasil penelitian eksperimen sebelum dan sesudah berkumur air rebusan daun kemangi terhadap $\mathrm{pH}$ saliva pada siswa SDN. 060933 Medan. Uji ini menggunakan aplikasi SPSS.

\section{Hasil Penelitian}

Hasil penelitian yang telah dikumpulkan terhadap siswa/i kelas V SDN 060933 Simpang Pos Padang Bulan Medan Tahun 2017. Setelah seluruh data terkumpul, membuat analisa data dengan cara membuat tabel distribusi frekuensi untuk masing-masing sampel. Kemudian dilakukan pengolahan data secara statistik, yaitu menggunakan uji satistik Wilcoxon Signed Ranks Test.

Tabel 4.1

Distribusi pH Saliva Sebelum Berkumur Air Rebusan Daun Kemangi Pada Siswa/I Kelas V SDN 060933 Simpang Pos Padang Bulan Medan Tahun 2017.

\begin{tabular}{|c|c|c|}
\hline \multirow{2}{*}{$\begin{array}{c}\text { Kriteria } \\
\text { pH saliva }\end{array}$} & \multicolumn{2}{|c|}{ Sebelum berkumur } \\
\hline & $\begin{array}{c}\text { Jumlah } \\
\text { (n) }\end{array}$ & $\begin{array}{c}\text { Persentase } \\
(\%)\end{array}$ \\
\hline Asam & 13 & 39,39 \\
\hline Netral & 7 & 21,21 \\
\hline Basa & 13 & 39,39 \\
\hline
\end{tabular}

Tabel 1 terlihat bahwa dari penelitian sebelum berkumur air rebusan daun kemangi frekuensi $\mathrm{pH}$ saliva terbesar adalah kriteria asam dan basa dengan persentase sama yaitu 13 orang $(39,39 \%)$. Sedangkan frekuensi $\mathrm{pH}$ saliva paling sedikit adalah kriteria netral dengan persentase 7 orang $(21,21 \%)$. 


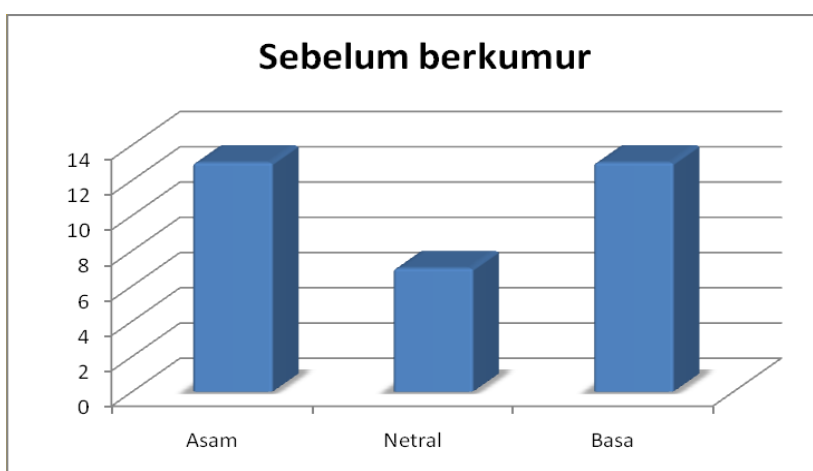

Grafik 5.1 Distribusi frekuensi berdasarkan jumlah pH saliva sebelum berkumur air rebusan daun kemangi pada siswa/i kelas V SDN 060933 Simpang Pos Padang Bulan Medan Tahun 2017.

Tabel 4.2

Distribusi pH Saliva Sesudah Berkumur Air Rebusan Daun Kemangi Pada Siswa/I Kelas V SDN 060933 Simpang Pos Padang Bulan Medan Tahun 2017

\begin{tabular}{|c|c|c|}
\hline \multirow{2}{*}{$\begin{array}{c}\text { Kriteria } \\
\text { pH saliva }\end{array}$} & \multicolumn{2}{|c|}{ Sesudah berkumur } \\
\hline & $\begin{array}{c}\text { Jumlah } \\
\text { (n) }\end{array}$ & $\begin{array}{c}\text { Persentase } \\
(\%)\end{array}$ \\
\hline Asam & 3 & 9,09 \\
\hline Netral & 12 & 36,36 \\
\hline Basa & 18 & 54,54 \\
\hline
\end{tabular}

Tabel 2 terlihat bahwa, kriteria $\mathrm{pH}$ setelah berkumur air rebusan daun kemangi terjadi penurunan jumlah asam dari 13 orang $(39,39 \%)$ menjadi 3 orang $(9,09)$. Kriteria $\mathrm{pH}$ saliva netral terjadi kenaikan dari 7 orang $(21,21 \%)$ menjadi 12 orang $(36,36 \%)$. Kriteria basa dari 13 orang $(39,39 \%)$ menjadi 18 orang $(54,54 \%)$.

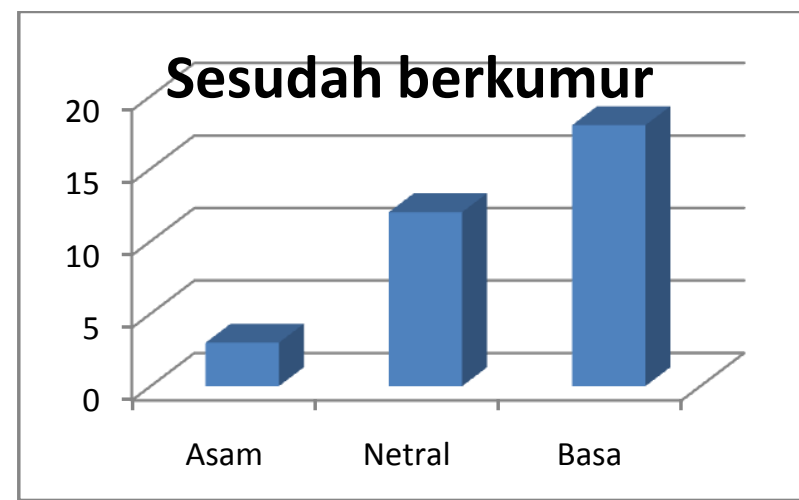

Grafik 5.2 Distribusi frekuensi berdasarkan jumlah pH saliva sesudah berkumur air rebusan daun kemangi pada siswa/i kelas V SDN 060933 Simpang Pos Padang Bulan Medan Tahun 2017.

Pengujian Hipotesis

Pengujian hipotesis penelitian ini menggunakan bantuan program statistika pada komputer menggunakan uji satistik Wilcoxon Signed Ranks Test untuk menguji distribusi data.
Tabel 4.3

Uji statistik Wilcoxon Signed Ranks Test $\mathrm{pH}$ saliva sebelum dan sesudah berkumur air rebusan daun kemangi pada siswa/i kelas $\mathrm{V}$ SDN 060933 Simpang Pos Padang Bulan Medan Tahun 2017.

\begin{tabular}{lc}
\hline \multicolumn{2}{c}{$p H$ sesudah berkumur $-p H$ sebelum } \\
berkumur \\
\hline Asymp. Sig. (2-tailed) & .007 \\
\hline
\end{tabular}

Dari tabel 3. dapat dilihat bahwa uji statistik Wilcoxon Signed Ranks Test didapatkan nilai signifikasi (2-tailed) sebesar 0,007. Nilai ini <0,05 sehingga dapat dinyatakan distribusi data normal.

Karena distribusi data normal, maka selanjutnya dilakukan uji statistik Paired T-test untuk melihat hubungan pada dua sampel yang berhubungan/berpasangan.

Tabel 4.4

Uji statistik Paired T-test pH saliva sebelum dan sesudah berkumur air rebusan daun kemangi pada siswa/i kelas V SDN 060933 Simpang Pos Padang Bulan Medan Tahun 2017.

\begin{tabular}{ccccc}
\hline & & \multicolumn{2}{c}{ Sig. } \\
& & $\mathrm{t}$ & $\mathrm{df}$ & (2-tailed) \\
\hline Pair 1 & $\mathrm{pH}$ sebelum berkumur & $-\mathrm{pH}$ sesudah \\
& Berkumur & -3.116 & 32 & 004 \\
\hline
\end{tabular}

Dari tabel 4.dapat dilihat bahwa uji statistik Pairet T-test didapatkan nilai t hitung sebesar -3,116, df (derajat kebebasan) sebesar 32 dan signifikasi (2-tailed) sebesar 0,004 (p-value <0,05). Karena nilai signifikasi (2tailed) <0,05 maka Ho ditolak dan Ha diterima.

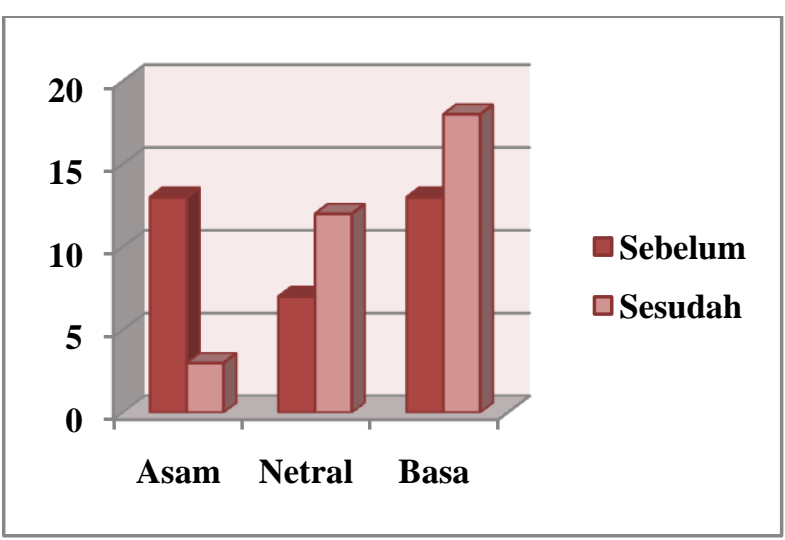

Grafik 5.2 Distribusi frekuensi berdasarkan jumlah pH saliva sebelum dan sesudah berkumur air rebusan daun kemangi pada siswa/i kelas V SDN 060933 Simpang Pos Padang Bulan Medan Tahun 2017.

Grafik diatas terlihat bahwa, kriteria $\mathrm{pH}$ setelah berkumur air rebusan daun kemangi terjadi penurunan jumlah asam dari 13 orang $(39,39 \%)$ menjadi 3 orang 
$(9,09)$. Kriteria $\mathrm{pH}$ saliva netral terjadi kenaikan dari 7 orang $(21,21 \%)$ menjadi 12 orang $(36,36 \%)$. Kriteria basa dari 13 orang $(39,39 \%)$ menjadi 18 orang $(54,54 \%)$.

\section{Pembahasan}

Hasil penelitian tentang pengaruh berkumur air rebusan daun kemangi terhadap $\mathrm{pH}$ saliva diperoleh data perubahan responden yang memiliki kriteria $\mathrm{pH}$ saliva asam yang mengalami penurunan sebanyak 9,09\%, kriteria $\mathrm{pH}$ saliva netral mengalami peningkatan menjadi $36,36 \%$ dan kriteria $\mathrm{pH}$ saliva basa mengalami peningkatan menjadi $54,54 \%$. Dari data tersebut diketahui bahwa dengan berkumur air rebusan daun kemangi terjadi perubahan kriteria $\mathrm{pH}$ saliva, hal ini dapat terjadi karena berbagai faktor yang terdapat di rongga mulut yang mempengaruhi $\mathrm{pH}$ saliva. Menurut pendapat Amerongen (1991) yang menyatakan bahwa $\mathrm{pH}$ saliva tergantung dari perbandingan asam dan basa. $\mathrm{pH}$ saliva dan kapasitas buffer saliva selalu dipengaruhi oleh perubahanperubahan diantaranya irama siang dan malam, perangsang kecepatan sekresi, sifat dan kekuatan rangsangan, diet, kadar hormon dan gerakan mulut. Saliva juga dapat bertindak sebagai buffer yang menetralkan kembali keadaan asam dan mulut (Afrilina dan Gracinia, 2006) Hal ini sesuai juga dengan penelitian Frida (2009) pada 38 orang sampel. Pada hasil nya diketahui dengan berkumur air rebusan daun kemangi terjadi perubahan $\mathrm{pH}$ saliva. Dengan berkumur air rebusan daun kemangi $\mathrm{pH}$ saliva cenderung kriteria basa.

Hasil pengolahan statistik pada penelitian ini, menggunakan uji Wilcoxon Signed Ranks Test dan uji Paired T-test menunjukkan hasil signifikasi dari analisa data pada $\mathrm{pH}$ saliva sebelum dan sesudah berkumur air rebusan daun kemangi diperoleh nilai signifikasi 0,004 (p-value $<0,05$ ). Diketahui hipotesis penelitian bahwa, hipotesa nol (Ho) ditolak dan hipotesa alternatif $(\mathrm{Ha})$ diterima. Yang berarti ada pengaruh berkumur air rebusan daun kemangi terhadap $\mathrm{pH}$ saliva pada siswa/i SDN kelas V SDN 060933 Simpang Pos Padang Bulan Medan tahun 2017.

Saliva membantu pertahanan email terhadap asam dengan cara menarik ion fluoride dan kalsium ke dalam emai (Afrilina dan Gracinia, 2006). Pendapat Pratiwi (2007) saliva berfungsi sebagai cairan pembersih dalam mulut sehingga dibutuhkan dalam jumlah yang cukup, tetapi kekurangan saliva akan membuat tingginya jumlah plak dalam mulut.

Tingkat keasaman saliva juga berpengaruh terhadap timbulnya karies pada gigi, semakin asam suatu $\mathrm{pH}$ saliva seseorang maka, semakin mudah terkena karies (Pratiwi, 2007). Pada umumnya, normal pH saliva sedikit asam yaitu 6,5. pH saliva totalnya yang tidak dirangsang biasanya agak asam, bervariasi dari 6,4 sampai 6,9. $\mathrm{pH}$ saliva setelah berkumur cenderung menjadi basa, sehingga terjadi kenaikan dengan kriteria basa. $\mathrm{pH}$ saliva bergantung pada kecepatan sekresi, dan kecepatan sekresi dipengaruhi oleh sifat rangsangan. Kenaikan $\mathrm{pH}$ saliva setelah berkumur dikarenakan rangsangan kimiawi dan mekanis yang didapatkan saat berkumur air rebusan daun kemangi.

\section{Simpulan}

Berdasarkan dari hasil penelitian Pengaruh Berkumur Air Rebusan Daun Kemangi Terhadap pH Saliva Pada Siswa/I kelas V SDN 060933 Simpang Pos Padang Bulan Medan dapat diuraikan sebagai berikut :

1. Frekuensi $\mathrm{pH}$ saliva terbesar sebelum berkumur air rebusan daun kemangi adalah kriteria asam dan basa dengan jumlah persentase sama yaitu 39,39\%.

2. Frekuensi $\mathrm{pH}$ saliva terbesar sesudah berkumur air rebusan daun kemangi adalah kriteria basa dengan jumlah persentase $54,54 \%$.

3. Dari hasil uji statistik Paired T-test diperoleh nilai signifikasi 0,004 karena p-value $<0,05$ berarti terdapat pengaruh berkumur air rebusan daun kemangi terhadap $\mathrm{pH}$ saliva. Dimana dengan berkumur air rebusan daun kemangi $\mathrm{pH}$ saliva cenderung ke kriteria basa.

\section{Saran}

Berkaitan dengan hasil penelitian diatas, maka peneliti memberikan saran sebagai berikut :

1. Bagi siswa/I kelas V SDN 060933 Simpang Pos Padang Bulan Medan untuk berkumur dengan obat kumur yaitu menggunakan air rebusan daun kemangi yang berfungsi untuk menetralkan atau meningkatkan $\mathrm{pH}$ saliva sehingga proses gigi berlubang dapat terhambat. Berkumur dilakukan sebanyak 2 kali sehari selama 30 detik.

2. Kepada Jurusan Keperawatan Gigi diharapkan agar hasil penelitian dapat digunakan sebagai materi penyuluhan alternatif tindakan pencegahan terjadinya karies.

\section{DAFTAR PUSTAKA}

Amerongen, A.V.N., 1991, Ludah dan Kelanjar Ludah Arti Bagi Kesehatan Gigi, Gadjah Mada University Press : Yogyakarta.

Anonim, 2009, Undang-Undang Republik Indonesia Nomor 36 Tahun 2009 Tentang Kesehatan, Pasal 3.

Arikunto, S, 2006, Prosedur Penelitian Suatu Pendekatan Praktek, PT Rineka Cipta : Jakarta.

Candra, Asep, 2011, Memetik Manfaat Daun Kemangi, www.health.kompas.com/memetik.manfaat.daun.ke mangi.html.

http//:www.frida.wordpress.com./kesehatangigimulut/kum urkemangisehatgigi.com download 20 Januari 2017

Depkes RI, 2004, Pedoman Upaya Kesehatan Gigi Masyarakat (UKGM), Depkes RI : Jakarta.

Hariana, Arief, 2008, Tumbuhan Obat dan Khasiatnya Seri 2, Swadaya : Jakarta.

Hendrawati, A.R.E., 2009, Uji Toksisitas Akut Ekstrak Etanol Daun Kemangi (Ocimum sactrum Linn.) Terhadap Larva Artemia salina Learch dengan Metode Brine Shrimp Lethality Test (BST), Fakultas 
Kedokteran Universitas Diponegoro : Semarang , http://eprints.undip.ac.id/8087/1/Anindita_Rosenda_ Eka_Hendrawati.pdf, download 14 Maret 2017.

Ircham, 1995, Menjaga Kesehatan Gigi dan Mulut, Liberty : Yogyakarta.

Kidd, E.A.M., dan Bechal, S.J., 1991, Dasar - Dasar Karies Penyakit dan Penanggulangannya, EGC : Jakarta.

Notoamodjo, Soekidjo, 2005, Metodologi Penelitian Kesehatan, PT Rineka Cipta : Jakarta.

Prasko, 2011, Pelayanan Asuhan Kesehatan Gigi, E-Book, www.ebook-prasko.blogspot.com, download 3 Januari 2012.

Pratiwi, Donna, 2007, Gigi Sehat Perwatan Gigi Seharihari, Kompas : Jakarta.

Simanjuntak, C.M.K, 2009, Hubungan Keadaan Saliva Dengan Resiko Karies Pada Siswa Kelas X SMK Negeri 9 Medan, Universitas Sumatera Utara : Medan,

http://repository.usu.ac.id/bitstream/123456789/2530 0/4/chapter\%2011.pdf.
Suwelo, I.S., 1992, Karies Gigi pada Anak dengan Pelbagai Faktor Etiologi, EGC : Jakarta.

Waid, Abdul, 2011, Dahsyatnya Khasiat Daun-Daun Obat di Sekitar Pekaranganmu, Laksana : Jogjakarta.

Winanto, Puguh, 2011, Info Kesehatan Daun Kemangi, http://forum.uii.ac.id/info-kesehatan-daun$\underline{\text { kemangi.html }}$ 